\title{
Monitor or Advise? How Family Involvement Affects Supervisory Board Roles in Family Firms
}

\author{
Dominik van Aaken $^{1} \cdot$ Maximilian Göbel $^{1} \cdot$ Daniel Meindl $^{2}$
}

Received: 11 July 2019 / Accepted: 6 April 2020 / Published online: 24 April 2020

(C) The Author(s) 2020

\begin{abstract}
This paper examines how the involvement of family members in family firms affects the roles of supervisory boards in two-tier board systems. Taking an agency and resource-based perspective, we argue that the occurrence of monitoring and advisory tasks of the board depends on the entanglement of family management and family ownership. This entanglement creates special governance requirements for family firms in two-tier board systems. We use a unique dataset of 186 German family firm observations to show that family involvement in management as well as a high family ownership reduces the occurrence of the monitoring tasks that the supervisory board performs. Moreover, we show that a growing number of owning family branches increases the monitoring tasks. We also provide evidence that family involvement increases the occurrence of the advisory tasks in relation to the monitoring ones.
\end{abstract}

Keywords Board roles · Board tasks · Family involvement · Family management · Family ownership $\cdot$ Supervisory board $\cdot$ Two tier board system

\section{JEL Classification M10}

D. van Aaken

Dominik.vanAaken@sbg.ac.at

M. Göbel

Maximilian.Goebel@stud.sbg.ac.at

D. Meindl

D.Meindl@bwl.lmu.de

1 Department of Business, Economics and Social Theory, University of Salzburg, Kapitelgasse 5-7, 5020 Salzburg, Austria

2 Institute for Accounting and Control, Ludwig Maximilian University of Munich, Ludwigstraße 28, 80539 Munich, Germany 


\section{Introduction}

A lot of recent research in the family firm literature is dedicated to the heterogeneities of family firms (e.g., Chua et al. 2012; Nordqvist et al. 2014; Songini and Gnan 2015). The rationale is that family firms are distinct by several features that result in specific behaviors such as family influence over strategies, intention to maintain control, succession plans, and capabilities that stem from family involvement (Chua et al. 1999). The heterogeneities in the population of family firms is rooted in the involvement of family members in management and ownership of family firms (Astrachan et al. 2002; Klein et al. 2005; Sharma and Nordqvist 2008). In this vein some scholars explored the impact of family involvement on the financial performance of family firms (e.g., Sacristán-Navarro et al. 2011; Audretsch et al. 2013), the risk of business failure (Revilla et al. 2016), or entrepreneurial orientation (Bauweraerts and Colot 2017). The peculiarities of the entanglement of ownership and management in family firms are also of particular interest for research on corporate governance (Debicki et al. 2009; Desender et al. 2013; Sherlock and Marshall 2019). Due to the occupation of multiple positions and the special relationship of actors within the firm, family firms offer a unique organizational setting to analyze the way boards of family firms work (Huse 2005).

While we know what roles the boards of directors usually perform, such as monitoring management and providing advice (e.g., Corbetta and Salvato 2004; Finkelstein et al. 2009; Hillman et al. 2000; Hillman and Dalziel 2003; Zattoni et al. 2015), research just started to draw attention on the relationship between family involvement and the performance of certain supervisory board roles. Desender et al. (2013), e.g., showed that firm ownership of family members has an impact on the magnitude of external audit fees contracted by the board. Songini and Gnan (2015) revealed the negative relationship between family governance and agency cost control mechanisms as well as the positive relationship between family management and agency cost control mechanisms (measured through six items as dummy variables). Zattoni et al. (2015) examined the mediating effects of board work between family involvement and firm performance. They found evidence that family involvement (measured as a dichotomous variable, if one or more families have a voting control of the firm and several generations of a family are involved in the management of the firm) has an impact on board processes and tasks. However, these studies focus exclusively on one-tier board systems and do not refer to the effects of family involvement in two-tier board systems.

Two-tier board systems differ from one-tier board systems by a strict organizational separation between the management and control functions of appointed board members (Hopt 1998). Information flows, and thus governance mechanisms, differ. A two-tier board system tries to prevent a dependence and bias of supervisory board members on their functions in order to protect both the interests of shareholders and the public (Jungmann 2006). However, the special setting of family firms in two-tier board systems, where there is an entanglement of family ownership and family management, might counteract the organizational separation and thus lead to changed governance conditions for the supervisory board. By combining insights from agency theory (Fama and Jensen 1983; Jensen and Meckling 1976) and the resource-based 
view (Barney 1991; Wernerfelt 1984), we address this research gap and suggest that the occurrence of monitoring and advisory roles of supervisory boards of family firms in two-tier board systems is determined by family involvement. Thereby, we account for different forms and extents of family influence on board roles by examining the effects of two dimensions: family management and family ownership. Assuming that family involvement in management and ownership is a key determinant for the prevalence of agency conflicts within the firm (Schulze et al. 2003a, 2001), we argue that family involvement determines how many monitoring tasks a supervisory board performs. Further, mobilizing a resource-based perspective, we argue that the prevalent knowledge of family and non-family managers determines how many advisory tasks the supervisory board performs.

Our study of 186 German family firm observations unveils the peculiarities of these two important board roles. First, we find that the number of monitoring tasks increases, if (a) the proportion of professional outside (i.e., non-family) managers increases, (b) the number of owning family branches rises, and (c) the ownership stake of outsiders (i.e., non-family members) grows. Second, our results indicate that the advisory role of the board becomes more dominant when the proportion of family managers in the top management team is low. Taken together, our results emphasize how family involvement explains the tasks that supervisory boards fulfill in two-tier board systems.

We add to the existing literature in the following ways. First, we delve deeper in the microprocesses of the supervisory board roles in family businesses. In particular, we provide a more detailed analysis of which particular monitoring and advisory tasks change with family-related determinants. Thereby, we show the peculiarities of the monitoring tasks that highly depend on the individual setting of the specific family involvement in the management and ownership of the firm. Second, our study demonstrates that family involvement has effects on board roles in two-tier board systems. As the literature on board roles mostly focuses on analyzing board roles of one-tier systems (e.g., Zattoni et al. 2015), empirical evidence on supervisory board roles of family firms accounting for the differing governance mechanisms of a twotier system is scarce (e.g., Bammens et al. 2011; Bettinelli 2011; Lohe and Calabrò 2017). We extend prior research by showing that the involvement of family members in ownership and management directly affects the magnitude of monitoring and advisory tasks of family firm supervisory boards in two-tier board systems-despite its crucial structural differences. Third, we shed light on a highly relevant topic: the workings of the boardroom. Past research on board roles of supervisory boards is most often conceptual (e.g., Forbes and Milliken 1999; Hillman and Dalziel 2003; Zahra and Pearce 1989). The few current studies that utilize empirical data are unable to provide in-depth insights as they do not rely on survey-based data (Hambrick et al. 2008; Daily et al. 2003) or primarily research board effects on firm financial performance (Lohe and Calabrò 2017; Zattoni et al. 2015). Utilizing survey data allows to draw a more detailed picture on the board work and shed light on the roles that supervisory board members inhabit. While most studies either focus exclusively on the monitoring role, the advisory role or the general level of board activity (e.g., Chrisman et al. 2007; Gomez-Mejia et al. 2001; Miller et al. 2013), we take a more integrative perspective as suggested by Bammens et al. (2011) and 
consider that boards may fulfill both a monitoring and an advisory role (e.g., Lohe and Calabrò 2017).

The remainder of this paper is organized as follows. By highlighting the peculiarities and determinants of supervisory board roles, the next section lays background to develop the research hypotheses of this study. The research methodology and research design employed is shown afterwards, followed by the presentation of our results. The last two sections are dedicated to the discussion and concluding remarks.

\section{Theoretical Background and Hypotheses Development}

Supervisory boards are independent governance bodies that serve prominent functions for organizations, and perform multiple tasks that may enhance the organizational value-creation process (Bammens et al. 2008). As such, board members are appointed by company stockholders to promote their interests within the firm, to recruit and supervise the firm's managing executives, to control a firm's strategy, and to monitor decision-making of top management teams (e.g., Withers and Hillman 2008). The core idea of dualistic systems with two separate boards is rooted in a strict separation of management and control, thereby protecting both shareholders and the public interest (Hopt 1998). This separation is often regarded as the key advantage of two-tier systems against one-tier systems: In one-tier systems information flows are open and non-exclusive as only one joint board exists and, thus, there is a certain risk that non-executive members are prone to a stronger dependence as they get in touch with operational topics of the firm (Belcher and Naruisch 2005). On the other hand, the strict separation of entities also leads to communication problems and information asymmetries. This is additionally driven by the supervisory board's size (Eisenberg et al. 1998). These differences are also reflected in the appointment of board directors in each system. The one-tier system is often subject to shareholder primacy, which is why independent executive directors or members of the financial industry are appointed to the board (Block and Gerstner 2016). In countries where two-tier board systems are common-such as Germany-, supervisory boards tend to follow a stakeholder primacy and, in addition to independent and dependent board directors, may also include employees to represent their interests on the supervisory board (depending on the size and legal form of the firm). In contrast, the management board is often solely composed of executive directors often having close ties to the firm and deals with the daily operations and management of the firm. While the superiority of either monistic or dualistic board systems is empirically unclear (Jungmann 2006) and an alignment of both systems through globalization is assumed (Zattoni et al. 2015), the differences between the two systems also result in varying governance requirements for the work of supervisory boards with regard to family firms. Whereas in one-tier systems family members need to be represented at board level in order to control the firm, control in the two-tier system can refer to both family representation in management and family representation on the supervisory board. While a large majority of countries impose either a one-tier or two-tier system on their companies, there are also countries, such as Belgium, Portugal or Spain, which gives companies the freedom to choose between the two 
forms of organization (Block and Gerstner 2016). However, most studies in the field of investigating board roles lack to account for these differences between board systems.

Although there is a long debate about the definition, characteristics, and number of board roles (Minichilli et al. 2012), the majority of the literature that deals with the working of the boardroom finds two board roles: monitoring and advisory (e.g., Corbetta and Salvato 2004; Finkelstein et al. 2009; Hillman et al. 2000; Hillman and Dalziel 2003; Zattoni et al. 2015). We follow van den Heuvel et al. (2006) as well as van Aaken et al. (2017) and aggregate groups of interrelated board tasks to board roles. Thereby, board tasks are sub-activities that boards fulfill within their board roles. Arguably, not all boards perform the same monitoring and advisory tasks. We conjecture that boards adjust to the governance requirements of the particular firm contingent on family involvement by allocating a greater number of particular board tasks under a particular board role. That is, we argue that each supervisory board solves its particular optimization problem subject to the governance needs of the respective firm (Adams et al. 2010). The advisory role is dominant both within the resource-dependence theory and the resource-based view (Barney 1991; Wernerfelt 1984). Both theories point out that supervisory boards may provide resources to firms that complement the management's capabilities, such as providing feedback or refining strategic proposals with different perspectives and experiences that supervisory board members obtained from other firms or industries (Westphal 1999), indicating new market opportunities (Zahra et al. 2000), or contribute to strategic decision-making (Finkelstein and Mooney 2003).

The monitoring role is emphasized in principal-agent theory. Principal-agent theory stresses that, in the presence of information asymmetries, organizational decision-makers may opportunistically maximize their personal utility, resulting in decisions conflicting with the preferences of their respective principals (Jensen and Meckling 1976). From this perspective, supervisory boards are institutions aimed at the mitigation of moral hazard problems by monitoring and disciplining executives (Fama and Jensen 1983). The vast majority of the corporate governance literature based on principal-agent theory assumes that family-firm settings differ with respect to the sources and severance of moral hazard due to the entanglement of ownership and control in comparison to non-family firms (e.g., Fama and Jensen 1983; Lubatkin et al. 2005). Classical agency conflict concerns the relationship between owners and managers of a firm. A common argument is that family firms are less prone to this type of conflict (e.g., Srinidhi et al. 2014). If a firm is entirely controlled by its owners, principal agent conflicts may not arise.

However, several authors have challenged this view (e.g., Bammens et al. 2011; Gomez-Mejia et al. 2011; Madison et al. 2015) as top management teams of family firms are usually mixed, i.e., comprised of family managers and professional (outside) managers. The argument that all consequences of the management's actions are borne by owners does not fully apply to most family firms. Even if professional managers are compensated, at least partially, based on their performance (Achleitner et al. 2010), incentives for perk consumption may persist. We argue that due to their powerful incentives, family managers may serve as "watchdogs" towards their nonfamily counterparts in the top management team. That is, they act as monitors inside 
the top management team and effectively represent the interests of the owners (Bammens et al. 2008). Taken to the extreme, family managers may bypass or sideline the supervisory board not only in terms of decision-making, but also in hampering the effective monitoring role of the supervisory board in a two-tier board system. As family managers, by definition, are also owners and have family ties to other major shareholders, they are likely to not only have incentives, but also means to discipline professional managers (Demsetz and Lehn 1985; Shleifer and Vishny 1997). Family managers are directly involved in day-to-day activities of the full top management team and therefore able to closely monitor the actions of outside managers. This type of intense monitoring limits the opportunities for undesired actions by outside managers. Thus, monitoring by family managers may substitute monitoring by the supervisory board (Rediker and Seth 1995; Audretsch et al. 2013).

In sum, we argue that the higher the proportion of family members in the top management team (i.e., the lower the proportion of non-family managers), the less opportunities remain for opportunistic behavior by outside managers (Ang et al. 2000). Given that monitoring by the board is costly (e.g., Faleye et al. 2011; van Aaken et al. 2017) and the dominance of rather informal governance systems in family firms (Calabrò et al. 2013), we expect supervisory boards to adapt to this low level of conflict between owners and managers. Consequently, the number of monitoring tasks in the family firm decreases. We formally hypothesize:

H1a The proportion of family members in the top management team of a firm is negatively associated with the number of monitoring tasks that the supervisory board performs.

The owner-manager relationship is not the only source of conflicts of interest in family firms. Due to their distinctive ownership structures with family blockholders, conflicts between different groups of owners may arise (e.g., Ang et al. 2000; McKnight and Weir 2009; Schulze et al. 2003a). As long as the owners of a firm share the same set of preferences, conflicts of interests may not exist (Eisenhardt 1989). Altruistic tendencies towards family members are likely to be strong in the parentchild relationship (Schulze et al. 2001). In these close relationships, opportunistic motives are likely to stand back and the risk of attempts to expropriate other owners is low. However, as the firm's ownership structure alters over generations and ownership has been passed on to several siblings, altruistic motives tend to create incentives for each sibling to maximize the welfare of their own nuclear family instead of that of the extended owning-family (Bammens et al. 2011; Lubatkin et al. 2005). That is, the emotional costs of expropriating other family branches decrease. Involved families tend to develop proprietary sets of idiosyncratic economic or noneconomic preferences (Schulze et al. 2003a). For instance, different family branches may have divergent attitudes towards risky business strategies or the succession plan. This development exacerbates when multiple family branches are involved because emotional attachments and mutual ties are diluted (Lubatkin et al. 2005). Moreover, as the number of owning-family branches rises, the number of passive family owners typically ascends because not every family branch can be personally represented in the top management team (Jaffe and Lane 2004). This increases the risk of actively 
involved family branches attempting to abuse their control at the expense of passive family branches. In this line, Desender et al. (2013) find a positive relationship between dispersed firm ownership and the monitoring function of boards (measured as external auditing fees contracted by the board). Corten et al. (2017) show that, if the level of family cohesion declines (which is the case with an increasing number of owning family branches), auditing demand is lower, when boards of directors are effective in their monitoring tasks. To summarize, a higher number of owning family branches may generally lead to a divergence of interest among owners and provides the breeding ground for multiple conflicts. We argue that the supervisory board is likely to respond to these exacerbated conflicts by performing multiple monitoring tasks:

H1b The number of owning family branches are positively associated with the number of monitoring tasks that the supervisory board performs.

In addition to ownership dispersion among different family branches, we also consider mixed ownership, i.e., firms that are owned by both family and non-family (outside) shareholders. Families constitute a special group of owners for two reasons and thus affect the roles of supervisory boards: First, they are usually poorly diversified and their economic welfare is crucially tied to the well-being of their business (Villalonga and Amit 2006). Second, families are typically long-term investors with the intention to transfer the firm to the next generation and to preserve the family's wealth and reputation (Shleifer and Vishny 1986; Wang 2006; Berrone et al. 2012). These properties lead to powerful monitoring incentives. Their dominant ownership position allows families to closely monitor the top management team without relying on formal and institutionalized mechanisms (Daily and Dollinger 1993; Geeraerts 1984). Therefore, we expect families with a high ownership stake to bypass the supervisory board and to use more direct forms of monitoring to lower the potential for information asymmetry between owners and managers. Direct monitoring by the owners is likely to substitute for monitoring activities by the supervisory board. In addition, Fang et al. (2017) find that the extent of family ownership is negatively related to the extent non-family managers can be found in family firms. Taken together, high family ownership increases the likelihood of significant goal congruence among owners and creates powerful monitoring incentives for the family themselves. Thus, we formally hypothesize:

H1c Total family ownership is negatively associated with the number of monitoring tasks that the supervisory board performs.

The separation of the supervisory board and management board in dualistic board systems may result in particular information asymmetries (Jungmann 2006). The management board has a clear knowledge advantage over the supervisory board due to its daily interaction with the management and operation of the firm. The supervisory board in turn depends on the information presented to it being adequate and comprehensive, not only to be able to monitor the firm successfully, but also to advise the management board on key issues. Again, the entanglement of ownership 
and management in family firms creates special governance requirements (Fama and Jensen 1983; Lubatkin et al. 2005). If there are many family members on the management board, the need to receive advice from family members on the supervisory board may decrease. Either family members on the supervisory board and management board have a similar knowledge base and do not need extensive advice, e.g. because they share knowledge in the family council or make use of informal organizational structures (De Kok et al. 2006), or family members may not accept advice from other family members because they are less receptive to feedback and advice from someone within the family (Eddleston et al. 2010). The more the management board in turn is dominated by outside (non-family) managers, the greater the need for advice may be. Although senior managers in family firms are often very experienced members of the firm and may have accumulated a lot of firm-specific knowledge, they may not be involved in all considerations of the family and therefore have a greater need for assistance and support in order to being able to follow the strategic directions of the family (Bammens et al. 2011, 2008). While outside managers may have an edge over their family manager counterparts in terms of general business knowledge (Anderson and Reeb 2004; Carney 2005), they may lack these intimate insights into the family business as they face challenges in understanding informal structures (De Kok et al. 2006), idiosyncratic goals and cultures (Vandekerkhof et al. 2015; Mitchell et al. 2003), as well as family biases in family firms (Verbeke and Kano 2012) and thus require further support by receiving advice from the supervisory board. Furthermore, non-family managers may also lack appropriate business networks or contacts in which family members are involved from an early age growing up in the family business (Bammens et al. 2011; Dyer 2006). In management boards dominated by outside managers, therefore, not only the need for advice, but also the integration into business networks is likely to play a greater role than in management boards dominated by family managers. Lastly, over time supervisory boards take care of a professionalization of the family firm, e.g. by replacing family managers by outside managers (Songini 2006; Stewart and Hitt 2012). In line with previous arguments, family members on the supervisory board may ideally provide the perspectives on the family's values and goals for the firm, beyond mere business insights, in order to advise an outsider-dominated management board. We therefore presume that the advisory role of the supervisory board becomes more important in outside manager dominated management teams.

H2 The proportion of family members in the top management team of a firm is negatively associated with the number of the advisory tasks of the supervisory board.

\section{Empirical Analysis}

\subsection{Study Design and Sample}

Obtaining data about the work of board members is difficult, due to the confidential nature of their work and thus constitutes the main reason for a lack of evidence in this research field. The most common empirical approach is combining publicly 
available information on board characteristics with data on observable firm actions (e.g., the acquisition or investment policy) trying to draw inferences on what supervisory boards actually do (Adams et al. 2010). We chose a survey-based approach as it provides access to detailed information on corporate governance variables of family firms that are barely disclosed to the public. Specifically, the survey allows us to ask directed questions on particular tasks that may or may not be covered by the board instead of drawing inferences from proxy variables, for instance, board size or board independence (Dichev et al. 2013). In 2003 and 2013, top management team members of family firms were contacted via email and requested to fill out a questionnaire. In 2003, firms were selected using the von Hoppenstedt database, one of the largest databases of German firms. ${ }^{1}$ The database contains basic information on German firms including a brief self-description. We screened the self-description texts for family firm indications, such as identical surnames among shareholders, to identify potential addressees. Applying this identification strategy, we collected 3000 firms, whereof 285 email addresses were not publicly available. Hence, we sent the questionnaire to 2715 , asking the CEO to answer our questions. We guaranteed all participants strict confidentiality and that the data will solely be used for scientific purposes in an anonymized form without any linkage to personal or firm identity. To offer maximum convenience, participants were provided the options to fill out the questionnaire online, to send it back via email, or to print it out and return it via post. To stimulate participation, respondents were offered a summary report of the survey results.

Incomplete responses and responses by firms which explicitly indicated that they do not self-identify as a family firm were filtered out. We ended up with 355 completed questionnaires in 2003. This corresponds to a response rate of about $10 \%$ which is similar to other studies (e.g., Bartholomew and Smith 2006). In 2013, we contacted firms that had participated in the first round in 2003 for a second time and requested to update the information by filling out the questionnaire once again. As 57 firms were bankrupt or merged, we finally contacted 298 firms and, after sending out several reminders, obtained 156 valid responses, corresponding to a response rate of $52 \%$ in 2013.

We started with an initial sample of 511 firm-year observations. We dropped 27 firm observations, as the respective firms did identify themselves as family firms, but did not meet the components of involvement approach in defining a family firm: family influence on ownership and management of the firm (Chua et al. 1999; Chrisman et al. 2005). In our operationalization, we have made sure that family firms are influenced by (at least) one family or family branch and that family members take an active role in the management and ownership of the firm, for example as executive director, supervisory board member, or senior management. Family members were considered as relatives by blood, marriage or adoption for the purposes of our investigation. Further, we excluded another 298 firm years as key variables were missing (177 firm-years were dropped for the lack of a supervisory board; 121 because other key variables like family involvement in management were missing), resulting in a final sample of 186 firm-year observations. We have used a two-wave

\footnotetext{
1 The family firm status was later verified on the basis of the information provided in the questionnaires.
} 
approach to leverage the existing access to family firms and to observe changes in board roles through changes in family involvement. In our empirical model, we considered intragroup correlation to adjust for our data setting. Table 1 documents that the majority of firms in the sample operate in the manufacturing industry $(55 \%)$ and employ between 100 and 1000 people (59\%). Most respondents are executives $(56 \%)$, while supervisory board members make up $7 \%$, and senior management $12 \%$ of total participants. 61 participants $(24 \%)$ are members of the founding family.

Table 1 Descriptive Statistics-Sample Firms

\begin{tabular}{|c|c|c|c|c|}
\hline & $\begin{array}{l}\text { Frequency } \\
\text { (2003) }\end{array}$ & $\begin{array}{l}\text { Frequency } \\
\text { (2013) }\end{array}$ & $\begin{array}{l}\text { Frequency } \\
\text { (Full Sam- } \\
\text { ple) }\end{array}$ & Percent \\
\hline \multicolumn{5}{|l|}{$\overline{\text { Industry }}$} \\
\hline Construction & 13 & 5 & 18 & 9.68 \\
\hline Manufacturing \& Industry & 69 & 34 & 103 & 55.38 \\
\hline Services & 12 & 8 & 20 & 10.75 \\
\hline Trade \& Retail & 17 & 11 & 28 & 15.05 \\
\hline Other & 10 & 7 & 17 & 9.14 \\
\hline Total & 121 & 65 & 186 & 100.00 \\
\hline \multicolumn{5}{|l|}{ Employees } \\
\hline 50-99 & 12 & 1 & 13 & 6.99 \\
\hline $100-499$ & 41 & 29 & 70 & 37.63 \\
\hline $500-1000$ & 27 & 13 & 40 & 21.51 \\
\hline$>1000$ & 41 & 22 & 63 & 33.87 \\
\hline Total & 121 & 65 & 186 & 100.00 \\
\hline \multicolumn{5}{|l|}{ Position of Respondent } \\
\hline Board Member & 5 & 12 & 17 & 6.88 \\
\hline Executive Director & 94 & 45 & 139 & 56.28 \\
\hline Family Member & 32 & 29 & 61 & 24.70 \\
\hline Senior Management & 21 & 9 & 30 & 12.15 \\
\hline Total & 152 & 95 & 247 & 100.00 \\
\hline \multicolumn{5}{|l|}{ Legal Form } \\
\hline AG & 39 & 16 & 55 & 29.57 \\
\hline $\mathrm{GmbH}$ & 29 & 18 & 47 & 25.27 \\
\hline $\mathrm{GmbH} \& \mathrm{Co}$ & 2 & 2 & 4 & 2.15 \\
\hline GmbH \& Co. KG & 46 & 24 & 70 & 37.63 \\
\hline KG & 3 & 4 & 7 & 3.76 \\
\hline Other & 2 & 1 & 3 & 1.64 \\
\hline Total & 121 & 65 & 186 & 100.00 \\
\hline
\end{tabular}

This panel presents descriptive statistics on general characteristics of sample firms. Industry (Industry Dummy) is the primary industry the firm operates in. Employees (employees ent $_{\text {) }}$ is the total number of employees. Position of Respondent (Respondent Dummy) is the respondent's position in the firm. Legal Form (capges $i, t)$ is the firm's legal form. 


\subsection{Measures}

\subsubsection{Dependent Variables: Supervisory Board Roles}

Following prior literature, we distinguish between two board roles, namely monitoring executives (monitoring role) and providing advice to executives (advisory role) (e.g., Corbetta and Salvato 2004; Finkelstein et al. 2009; Hillman et al. 2000; Hillman and Dalziel 2003). We aggregate groups of interrelated board tasks to board roles (Van den Heuvel et al. 2006). Board tasks are sub-activities boards fulfill. Empirically, we measure both board roles as an aggregation of tasks that the supervisory board may or may not perform. In particular, participants were asked to indicate whether or not specific tasks are part of the board's work. We count the number of tasks assigned to the monitoring (advisory) role executed by the supervisory board and determine to what extent the board fulfils a monitoring (advisory) role.

We draw on governance literature and derive eleven tasks (Hillman and Dalziel 2003). The items reflect tasks that are typically assigned to supervisory boards (in family firms) and cover both monitoring (e.g., assessment and approval of the firm's strategy, settlement of the issue of succession) and advisory tasks (e.g., provision of knowledge, provision of access to business networks). Although there is some conceptual and theoretical guidance, there are two difficulties associated with the aggregation of supervisory board tasks to roles. First, for some tasks the literature is inconclusive about the appropriate assignment. For instance, some scholars assign the mediation of conflicts among different groups of owners to the monitoring role (e.g., Schulze et al. 2001), while other authors assign this task to the advisory role (e.g., Barach 1984). Second, the conceptual level of disaggregation of board roles is unclear. Scholars discuss frameworks with two (e.g., Hillman et al. 2000; Hillman and Dalziel 2003), three (e.g., Johnson et al. 1996; Pearce and Zahra 1992), or more ${ }^{2}$ distinct board roles. To address this conceptual inconsistency and to validate our task

Table 2 Supervisory Board Roles (Factor Analysis)

\begin{tabular}{lll}
\hline Items & \multicolumn{2}{l}{ Factor Loadings } \\
& Monitoring & Advisory \\
\hline Assessment and approval of the firm's strategy & 0.56 & - \\
Provision of support and assistance to the management team & - & 0.44 \\
Provision of access to business networks & - & 0.76 \\
Mediation between owners and management & 0.46 & - \\
Monitoring of the management team & 0.60 & - \\
\hline Eigenwert & 1.95 & 1.11 \\
Variance explained & $32 \%$ & $18 \%$ \\
KMO & $>0.65$ & \\
\hline
\end{tabular}

This panel presents the results of the factor analysis; Extraction Method Principal Component Analysis, Rotation Method Unrotated (Principal); only items that load with $>0.40$ on any factor were considered.

2 See van den Heuvel et al. (2006) for a comprehensive review of various board role definitions in the family firm literature. Generally, most definitions share a high degree of similarity, but highlight the importance 
aggregation strategy, we conduct an explorative factor analysis (EFA; cp. Table 2). EFA yields two different factors with Eigenvalues greater than one. Accordingly, we extract two supervisory board roles. In line with the literature on supervisory boards, we label these roles monitoring and advisory. Only factor loadings larger than 0.4 are considered which excludes six items. These six items include tasks such as defining a family strategy, which can also take place in an informal body such as the family council rather than the supervisory board. The KMO score of 0.66 indicates that factor analysis is appropriate. To further validate the adequacy of the EFA, we also conduct a confirmatory factor analysis (CFA). CFA supports the validity, indicating a good model fit (RMSEA <0.05; CFI >0.95; CD >0.99).

As a result of the factor analysis, the monitoring role captures following tasks: assessment and approval of the firm's strategy, mediation between owners and management, and monitoring of the management team (Cronbach's Alpha of 0.75). The advisory role captures following tasks: provision of support and assistance to the management team and provision of access to business networks (Cronbach's Alpha of 0.92). Taken together, the CFA goodness of fit statistics, the Cronbach's Alpha coefficients and the consistency with theory suggest a high level of adequacy of the two extracted supervisory board roles.

\subsubsection{Independent Variables: Family Involvement}

We apply three different measures of family involvement. The first measure $\left(\right.$ family_mgmt $\left._{i, t}\right)$ captures family management in the form of representation of family members in the top management team. The two remaining measures, the number of owning family branches (numb_families $s_{i, t}$ ) and total family ownership stake (family_share ${ }_{i, t}$ ), relate to family ownership.

We include family_mgmt $i_{i, t}$ in order to quantify family involvement in the top management team. In analogy to Villalonga and Amit (2006), the variable is defined as the percentage of family members in the top management team. In our sample, the average fraction of family members in the top management team is $45 \%$. As a measure of ownership dispersion among families, we use the variable numb_families f $_{i, t}$. The variable is defined as the number of owning families of a firm. In our final sample, $41 \%$ of firms are owned by more than one family branch. ${ }^{3}$ While, by definition, family firms are at least to a certain degree owned by one or more families, firms are not necessarily exclusively family-owned. In our final sample, $24 \%$ of firms have at least one outside (non-family) shareholder. In line with other family firm studies (e.g., Villalonga and Amit 2006), we use the variable family_share ${ }_{i, t}$ as a measure for goal alignment among owners. The logarithmized variable reflects the percentage of firm shares that are held by the owning family.

of particular tasks. For instance, Johnson et al. (1996) explicitly split the advisory role into a service role and a resource-dependence role, while most other authors consider service and the provision of resources as components of the advisory role.

3 To measure the ownership dispersion among different owning family branches, some studies use the generational lifecycle stage of the firm as a variable (Bammens et al. 2008). We consider the number of involved family branches a more direct measure for the potential rise of interfamily conflicts. However, we include the generational lifecycle stage as a control variable. 


\subsubsection{Control Variables}

We consider both family-firm related and general firm-specific control variables. We use the total number of employees (employees ent, $_{\text {e }}$ ) to control for firm size. To control for the impact of family members in non-executive positions (i.e., staff), we use an indicator (family_employe $e_{i, t}$ ) that takes on the value of 1 , if there are family members employed as staff and 0 else. The rationale behind this is that any involvement of family members in the firm may influence supervisory board roles. Moreover, family members may serve as members of the supervisory board. It has been shown that board composition impacts numerous board-related topics. For instance, Hope et al. (2012) document for a sample of private family firms that audit fees decrease as the proportion of board members from the largest owning family increases. Hillman and Dalziel (2003) argue that board composition determines the board's ability to provide resources ("board capital") to management. We use the ratio of the number of family members on the supervisory board to the total number of supervisory board members (board_comp $p_{i, t}$ ) as a proxy to account for this issue. We also control for board size as Huse (1990) reports that board size is negatively correlated with the board's involvement as counselors for the CEO in small and medium-sized enterprises (SME). Moreover, the larger the supervisory board the more agency-conflicts may arise and the less decisive and effective in overseeing management it might be (Eisenberg et al. 1998). The supervisory board size variable $\left(\right.$ size_board $_{i, t}$ ) is defined as the number of supervisory board members $(\min =1, \max =12$ board members $)$. Moreover, we employ an indicator variable whether the firm is legally required to install a supervisory board $(=1)$ or not $\left(\right.$ mandatory_s $\left.b_{i, t}\right)$. German law prescribes a mandatory supervisory board for stock companies and private limited partnerships by shares, and requires a supervisory board for limited liability companies and cooperatives, if they exceed a certain firm size. For other types of firms, it is optional to install supervisory boards. In line with related literature, we further include firms' equity ratio (equity $y_{i, t}$ ) as a control variable (Srinidhi et al. 2014; Schulze et al. 2003b) for capital structure as external providers of credits and loans may have monitoring incentives (e.g., Ang et al. 2000). We defined equity ratio as ratio of total equity to total assets. Respondents were provided three options: less than $20 \%(=1)$, between 20 and $50 \%(=2)$, and more than $50 \%(=3)$. Furthermore, we include the generational lifecycle stage as a control variable to address the role of family business experience. Corbetta and Salvato (2004) argue that the accumulated business experience in the family affects the provision of resources by the board. To measure this construct, we asked respondents to indicate which family generations were actively involved in the firm (five separate dummy variables from first to fifth generation involved where each takes the value 1, if that generation is involved in the management and/or ownership of the firm and 0 if not; Generation Dummy). Also, to mitigate a potential respondent bias, we include indicator variables for the respondent's respective position in the firm (supervisory board member, executive, family member, senior management; Respondent Dummy). Lastly, we employ indicator variables for respective industries (construction, manufacturing, services, trade and retail, and other; Industry Dummy). 


\subsection{Empirical Model}

To test our hypotheses on how different dimensions of family influence affect supervisory board roles, we estimate the following equation:

$$
\begin{aligned}
& B R_{i, t}^{k}=\beta_{0}+\beta_{1} \times \text { family_mgmt }_{i, t}+\beta_{2} \times \text { numb_families }_{i, t}+\beta_{3} \times \text { family_share }_{i, t} \\
& + \text { Controls }_{i, t}+\varepsilon_{i, t},
\end{aligned}
$$

where:

$B R_{i, t}^{k}=$

family_mgmt $_{i, t}=$ numb_families $i, t=$ family_share $i, t=$

Controls $_{i, t}=$ number of tasks assigned to role $k$ ( $k=$ monitoring, advisory) performed by the supervisory board, proportion of family members in the top management team, number of family branches owning shares in the firm, proportion of the number of shares held by all owning family branches to total shares issued, total number of employees, family member as a non-executive employee, proportion of family members on the supervisory board, board size, legal obligation to install a supervisory board, capital structure, generational lifecycle stage of the firm, position of the respondent, industry.

\section{Results}

The appendix provides descriptive statistics for the family involvement and board characteristics variables of the 186 firm-year observations. In addition to our three independent variables (family management, number of owning families and family ownership share), we report three further measures of family involvement, namely a dummy for family members as non-executive employees, involved generation(s) and board composition. The descriptive statistics indicate that the proportion of family members in the top management teams of the sample is $45 \%$. The median proportion of $50 \%$ and the lower and upper quartiles, $17 \%$ and $67 \%$, respectively, suggest that most management teams are comprised of both family members and outsiders. Whilst on average, $58.59 \%$ of firms are owned by a single family (branch), $41.41 \%$ of the firms in our sample have two or more owning family branches. Sixteen firms $(8.61 \%)$ in the sample are owned by more than three family branches. The distribution of total family ownership stakes is strongly skewed to the right as the median firm is exclusively family-owned. On average, $92 \%$ of shares of sample firms are concentrated in the hands of one or more owning family branches. Moreover, $73.66 \%$ of sample firms employ family members in non-executive positions. In addition, we find a large variety in the firms' generational lifecycle stage. The most commonly involved generation is the third. In 38 cases, the fifth or higher generation is involved, indicating that these firms have reached a mature stage. ${ }^{4}$ Board composition statistics document a heavy representation of family members in super-

\footnotetext{
4 Note, that in some cases two family generations can simultaneously be involved in the firm. In fact, 80 respondents indicated that there are currently two generations actively involved in the business. Hence,
} 
Table 3 Supervisory Board Roles

\begin{tabular}{lllll}
\hline Number of Tasks & Monitoring & & Advisory & \\
& Frequency & Percent & Frequency & Percent \\
\hline 0 & 11 & 5.91 & 12 & 6.45 \\
1 & 15 & 8.06 & 143 & 76.88 \\
2 & 51 & 27.42 & 31 & 16.67 \\
3 & 109 & 58.60 & - & - \\
Total & 186 & 100.00 & 186 & 100.00 \\
\hline
\end{tabular}

This panel presents descriptive statistics on the monitoring role variable $\left(s b \_\right.$monitor $\left.i, t\right)$ and the advisory role variable (sb_advisory $i, t)$.

visory boards. On average, family members hold $63 \%$ of supervisory board seats. The proportion of family members in the supervisory board is considerably higher than in the top management team. Besides the six measures of family involvement, two more variables capturing supervisory board characteristics are examined: In our sample, average (median) supervisory boards consist of 4.73 (4) directors. Furthermore, $58.06 \%$ of firms are legally obliged to install a supervisory board due to the firm's legal form and/or size.

Table 3 reports the respective number of monitoring and advisory tasks performed by the supervisory board. While $5.91 \%$ of respondents indicate that the supervisory board does not carry out one of the three specified monitoring tasks, another $58.60 \%$ stated that the board performs all three tasks. The majority of boards $(76.88 \%)$ carries out one task assigned to the advisory role.

Table 4 displays the pairwise correlation matrix. It shows a significant positive correlation between the two board roles. However, the relations of the two respective board roles with independent variables differ considerably. For the advisory role, there is a significant negative relation with the variable capturing the proportion of family members in the top management team. For the monitoring role, the matrix documents significant negative associations for the proportion of family members in the top management team and the total stake of owning families. Moreover, there is a significant positive correlation between the monitoring role and the number of owning families. Hence, the pairwise correlations support the idea of differences in the determinants of the occurrence of respective board roles and are consistent with our hypotheses. The high correlation between employees $_{i, t}$ and mandatory_s $b_{i, t}$ is due to the greater likelihood that larger firms will operate in a legal form that requires a mandatory supervisory board. The two significant correlations of employees $i, t$ support two ideas: first, larger firms tend to be older and may have gone through the process of professionalizing their management, which is why there are fewer family managers and more outside managers on the management board (e.g., Fang et al. 2017); second, the larger (and older) a family firm is, the more family generations and thus family branches may be shareholders of the firm. The correlations of size_board $_{i, t}$ also support the observation that larger boards can be found in older and larger firms. Therefore it is positively correlated with employees $s_{i, t}$ Larger or

in the table "Involved Generation" the frequency column for the full sample does not add up to 186 (actual number of firm-year observations in the full sample). 


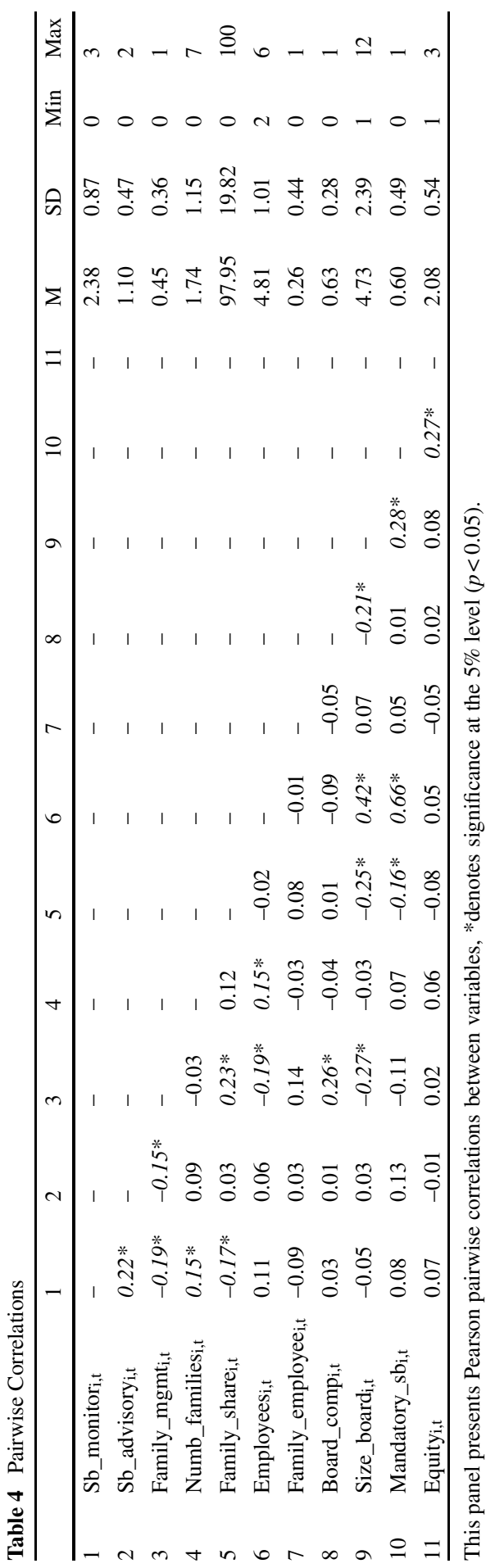


older firms may also have fewer family managers (significant negative correlation with family_mgmt $t_{i, t}$ ), the family share may has become smaller over time (significant negative correlation with family_share $i_{i, t}$ ) and the supervisory board may has fewer family members due to codetermination or new shareholders (significant negative correlation with board_comp $p_{i, t}$ ). Also, all other correlations among control variables are reasonably low. We calculated the variance inflation factors (VIF) for both the monitoring and advisory role models. The VIF values for each variable are below ten for both models and thus give us no indication of multicollinearity issues (Mansfield and Helms 1982).

Table 5 reports the regression results for the determinants of the number of monitoring tasks of the supervisory board. As we find observations from two periods for most firms in our sample (2003 and 2013), we base our empirical models on clustered ordered probit to address the effects of intragroup correlation. Models (I), (II) and (III) document univariate results for each independent variable. Model (IV) comprises all three independent variables but does not include any control variables. Model (V) is the full model including all independent and control variables. To assess the robustness of the results, we test if our results are biased by our choice of clustered ordered probit and additionally estimate the models using clustered ordered logit regression (Long and Freese 2006). The ordered logit estimation results for the monitoring role are presented in Column (VI).

Table 6 reports the regression results for the number of advisory tasks of supervisory boards. Model (I) reports the univariate results. Model (II) presents the full model including all control variables. Model (III) shows the results of the ordered logit model. Again, clustered regression was applied for all models.

Hypothesis 1a assumed that the proportion of family members in the top management team diminishes the number of monitoring tasks of the supervisory board. In line with our expectations, models (I), (IV) and (V) document a significant negative association between the proportion of family members in the top management team and the number of tasks assigned to the monitoring role (model (I), $p<0.01$; model (IV), $p<0.05$; model (V), $p<0.01$ ). Hypothesis $1 \mathrm{~b}$ predicts that the number of owning family branches increases the number of monitoring tasks of the supervisory board. The corresponding coefficients in models (II), (IV) and (V) unanimously support the expected relation (model (II), $p<0.05$; model (IV), $p<0.05$; model (V), $p<0.05)$. Hypothesis 1c suggests a negative association between the total family ownership and the number of monitoring tasks that the supervisory board performs. The respective coefficients in models (III), (IV) and (V) provide evidence for this expectation (model (III), $p<0.01$; model (IV), $p<0.01$; model (V), $p<0.01$ ). Hypothesis 2 assumes a negative association between the proportion of family members in the top management team and the importance of the board's advisory role. The estimated coefficients in model (I) and (II) in Table 6 suggest that there is a (weak) significant negative association (model (I), $p<0.05$; model (II), $p<0.1$ ). The result of the ordered logit regression is qualitatively unchanged, but insignificant. 


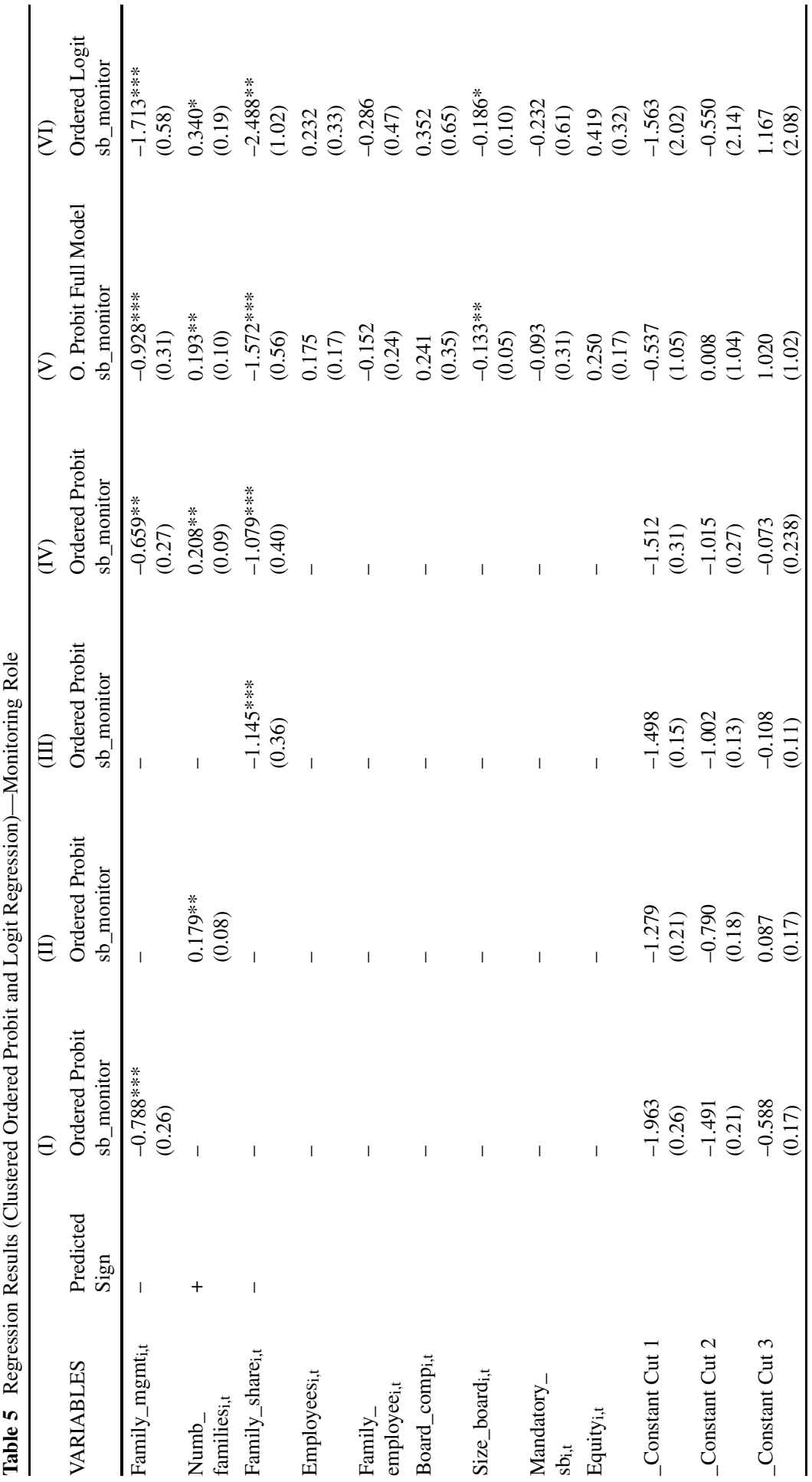




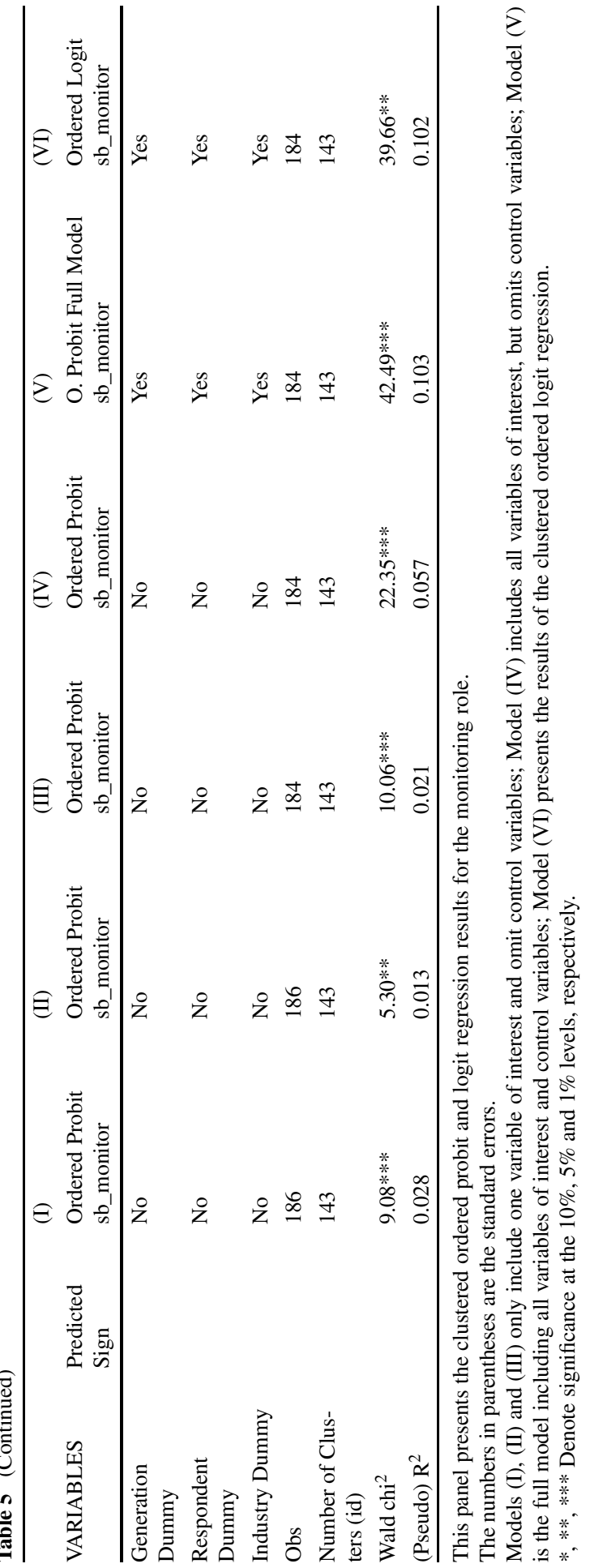


Table 6 Regression Results (Clustered Ordered Probit and Logit Regression)—Advisory Role

\begin{tabular}{|c|c|c|c|c|}
\hline & & (I) & (II) & (III) \\
\hline VARIABLES & $\begin{array}{l}\text { Predicted } \\
\text { Sign }\end{array}$ & $\begin{array}{l}\text { Ordered Probit } \\
\text { sb_advisory }\end{array}$ & $\begin{array}{l}\text { O. Probit Full Model } \\
\text { sb_advisory }\end{array}$ & $\begin{array}{l}\text { Ordered Logit } \\
\text { sb_advisory }\end{array}$ \\
\hline Family_mgmt ${ }_{i, t}$ & - & $\begin{array}{l}-0.543^{* *} \\
(0.27)\end{array}$ & $\begin{array}{l}-0.527^{*} \\
(0.32)\end{array}$ & $\begin{array}{l}-0.969 \\
(0.66)\end{array}$ \\
\hline Numb_familiesi,t & & - & $\begin{array}{l}0.108 \\
(0.09)\end{array}$ & $\begin{array}{l}0.172 \\
(0.18)\end{array}$ \\
\hline Family_share $_{i, t}$ & & - & $\begin{array}{l}0.243 \\
(0.27)\end{array}$ & $\begin{array}{l}0.475 \\
(0.52)\end{array}$ \\
\hline Employeesi,t & & - & $\begin{array}{l}-0.162 \\
(0.14)\end{array}$ & $\begin{array}{l}-0.386 \\
(0.26)\end{array}$ \\
\hline Family_employee, tt & & - & $\begin{array}{l}0.142 \\
(0.22)\end{array}$ & $\begin{array}{l}0.236 \\
(0.44)\end{array}$ \\
\hline Board_comp $p_{i, t}$ & & - & $\begin{array}{l}0.366 \\
(0.36)\end{array}$ & $\begin{array}{l}0.611 \\
(0.70)\end{array}$ \\
\hline Size_board ${ }_{i, t}$ & & - & $\begin{array}{l}-0.040 \\
(0.05)\end{array}$ & $\begin{array}{l}-0.051 \\
(0.11)\end{array}$ \\
\hline Mandatory_sb ${ }_{i, t}$ & & - & $\begin{array}{l}0.433 \\
(0.30)\end{array}$ & $\begin{array}{l}0.852 \\
(0.60)\end{array}$ \\
\hline Equityi,t & & - & $\begin{array}{l}-0.013 \\
(0.20)\end{array}$ & $\begin{array}{l}-0.029 \\
(0.40)\end{array}$ \\
\hline _Constant Cut 1 & & $\begin{array}{l}-1.785 \\
(0.21)\end{array}$ & $\begin{array}{l}-2.600 \\
(1.05)\end{array}$ & $\begin{array}{l}-4.629 \\
(2.13)\end{array}$ \\
\hline _Constant Cut 2 & & $\begin{array}{l}0.745 \\
(0.16)\end{array}$ & $\begin{array}{l}0.206 \\
(1.05)\end{array}$ & $\begin{array}{l}0.263 \\
(2.11)\end{array}$ \\
\hline $\begin{array}{l}\text { Generation } \\
\text { Dummy }\end{array}$ & & No & Yes & Yes \\
\hline $\begin{array}{l}\text { Respondent } \\
\text { Dummy }\end{array}$ & & No & Yes & Yes \\
\hline $\begin{array}{l}\text { Industry } \\
\text { Dummy }\end{array}$ & & No & Yes & Yes \\
\hline Obs & & 186 & 184 & 184 \\
\hline $\begin{array}{l}\text { Number of } \\
\text { Clusters (id) }\end{array}$ & & 143 & 143 & 143 \\
\hline Wald chi $^{2}$ & & $4.11 * *$ & $39.49 * *$ & $37.42 * *$ \\
\hline (Pseudo) $\mathrm{R}^{2}$ & & 0.018 & 0.099 & 0.094 \\
\hline
\end{tabular}

This panel presents the clustered probit and logit regression results for the advisory role.

The numbers in parentheses are the standard errors.

Model (I) only includes one variable of interest and omits control variables.

Model (II) is the full model including all variables of interest and control variables.

Model (III) presents the results of the clustered ordered logit regression.

$*, * *, * * *$ Denote significance at the $10 \%, 5 \%$ and $1 \%$ levels, respectively. 


\section{Discussion}

Family firms differ from other types of business, especially due to the involvement of family members in the management and ownership of the firm. The entanglement of management and ownership create special conditions for the governance requirements of these firms and thus also affects how the members of supervisory boards perform their work in two-tier board systems. In the present study, we examined how family management and family ownership affect the occurrence of the two major supervisory board roles: monitoring management and the provision of advice. We make a number of contributions to the existing literature on family firms and corporate governance.

First, using survey-based data, our results suggest that family involvement indeed is a strong factor explaining the way supervisory boards work. More specifically, our results indicate that a higher family involvement diminishes the need for supervisory boards to engage in monitoring the management board. This result is consistent with two effects of the presence of family members in the top management team. First, the outcomes of management decisions are internalized as family managers are also owners of the firm (Fama and Jensen 1983). This naturally reduces conflicts of interest arising from the separation of ownership and control. Second, family managers may exert a monitoring role in the sense that the actions of their nonfamily counterparts are observable for them due to communication and a constant flow of information among members of the top management team thereby bypassing the supervisory board (Demsetz and Lehn 1985; Shleifer and Vishny 1997). That is, the monitoring of non-family managers by family managers can be considered a substitute for monitoring by the supervisory board (Rediker and Seth 1995).

Second, our results implicate that the more family branches are involved in the ownership of a firm, the more monitoring tasks by the supervisory board are required. We suggest that the reasons for this relationship might be divergent underlying rationales between different family branches and incompatible concepts for the firm's strategic focus. Also, some family branches may start to maximize their own nuclear welfare at the expense of other (maybe minor) owning family branches by expropriation (Bammens et al. 2011; Lubatkin et al. 2005; Schulze et al. 2003a). These conflicts and tensions require more emphasis on the monitoring role of the supervisory board.

Third, the more shares a family owns of a family business, the more likely it is that the number of monitoring tasks of the supervisory board decreases. This finding of our study is consistent with the notion that, while an owning family as a large blockholder has powerful monitoring incentives, it does not rely solely on the supervisory board to enforce its interests (Daily and Dollinger 1993; Geeraerts 1984). Instead, ownership enables informal and non-institutionalized forms of monitoring. This may lead to a less pronounced monitoring role of the supervisory board.

Finally, our results also indicate that boards perform more advisory tasks, when the proportion of non-family managers increases. That is, the need for expertise is higher when non-family members predominantly manage the firm. This relation is based on different access to information and knowledge bases between the management board and the supervisory board in dualistic systems (Jungmann 2006). 
The entanglement of ownership and management in family firms entails that family managers have different access to information flows and a knowledge advantage over outside managers, which is why there is less need for advice from the supervisory board. Moreover, non-family managers may not have the same access to business networks (Bammens et al. 2011), have challenges in understanding familyfirm specific factors such as informal organizational structures (De Kok et al. 2006; Mitchell et al. 2003), idiosyncratic goals and culture of the family firm (Vandekerkhof et al. 2015). Notably, we did not find a significant correlation between the proportion of family members in the supervisory board and the number of advisory tasks. This backs the idea that the supervisory board's perception of the need for the provision of additional resources is primarily driven by the composition of the top management team (Finkelstein and Mooney 2003; Westphal 1999; Zahra et al. 2000). Therefore, boards carry out more tasks assigned to the advisory role if the family's participation in the top management team diminishes. Although it is obviously no clear evidence for the lack of a relation, it is still noteworthy, that our results do not indicate any statistical relation between family ownership variables (i.e., the number of owning family branches, total family ownership stake) and the board's advisory role. While the number of monitoring tasks is affected by both ownership and control, we merely find evidence for the influence of control (i.e., the proportion of family members in the top management team) on the number of advisory tasks.

Overall our results document that the proportion of family members impacts the number of monitoring and advisory tasks alike. We find evidence that a high proportion of family members in the management team reduces the occurrence of both roles. Due to the measurement of the dependent variables, it is not reasonable to compare the respective coefficients in Tables 5 and 6 in order to determine relative effects. Therefore, we estimate a new model with the logarithmized ratio of the number of advisory tasks to the number of monitoring tasks of supervisory boards as dependent variable. Table 7 reports the results for that OLS regression. The estimated coefficient is significant at the 5\% level and indicates that, as the proportion of family members in the top management team rises, the occurrence of the advisory role increases relative to the monitoring role. Moreover, it indicates that the complete ownership of a family firm's shares by a family further increases the number of advisory tasks of the supervisory board. This may again underline that agency conflicts become less salient in firms with high family involvement and thus reinforces advisory tasks of the board.

The results of this study are bound by the limitations that are inherent in our research design. First, our sampling frame and context is restricted to German family firms. The generalizability of our results to other regulatory and cultural environments may thus be limited. Future studies may consider our proposed hypotheses across different countries or facilitate replication studies in countries having as well two-tier board systems (e.g., China) to investigate the effects of peculiarities of different institutional contexts (Aguilera and Jackson 2010), market and environmental conditions (Kim et al. 2009) or firm life cycle (Huse and Zattoni 2008). Second, as most studies that deal with the work of boards, we are limited in our ability to examine the real interactions, microprocesses and roles of supervisory board mem- 
Table 7 Multivariate Results (Clustered OLS)—Relative Importance of Board Roles

\begin{tabular}{|c|c|}
\hline VARIABLES & $\begin{array}{l}\text { OLS } \\
\frac{s b \_a d v i s o r y}{s b \_m o n i t o r}\end{array}$ \\
\hline Family_mgmt ${ }_{i, t}$ & $\begin{array}{l}0.257^{* *} \\
(0.11)\end{array}$ \\
\hline Numb_familiesi,t & $\begin{array}{l}-0.015 \\
(0.03)\end{array}$ \\
\hline Family_share $_{i, t}$ & $\begin{array}{l}0.201 * * \\
(0.09)\end{array}$ \\
\hline Employees $_{\mathrm{i}, \mathrm{t}}$ & $\begin{array}{l}-0.072 \\
(0.05)\end{array}$ \\
\hline Family_employee & $\begin{array}{l}-0.017 \\
(0.08)\end{array}$ \\
\hline Board_comp $\mathrm{i}_{\mathrm{i}, \mathrm{t}}$ & $\begin{array}{l}0.062 \\
(0.11)\end{array}$ \\
\hline Size_boardi,t $_{i, t}$ & $\begin{array}{l}0.006 \\
(0.02)\end{array}$ \\
\hline Mandatory_sb $b_{i, t}$ & $\begin{array}{l}0.213^{* *} \\
(0.10)\end{array}$ \\
\hline Equityi,t & $\begin{array}{l}-0.099 \\
(0.07)\end{array}$ \\
\hline _Constant & $\begin{array}{l}-0.531 \\
(0.42)\end{array}$ \\
\hline Generation Dummy & Yes \\
\hline Respondent Dummy & Yes \\
\hline Industry Dummy & Yes \\
\hline Obs & 165 \\
\hline Number of Clusters (id) & 133 \\
\hline F-value & $2.19 * * *$ \\
\hline$\underline{\mathrm{R}^{2}}$ & 0.175 \\
\hline
\end{tabular}

This panel presents clustered OLS regression results for the importance of the advisory role relative to the importance of the monitoring role.

The numbers in parentheses are the standard errors.

$*, * *, * * *$ Denote significance at the $10 \%, 5 \%$ and $1 \%$ levels, respectively.

bers, executives and the top management team. Also, our research is based on the subjective perceptions of family firm upper echelons about the roles that the supervisory board performs. Despite the habitualness of this research setting and the advantages of top managers being the most objective source for self-assessments of firms (Pearce and Zahra 1991), self-reported data may be prone to biases and hence under- or overestimate the occurrence of supervisory board tasks (Pugliese et al. 2014).

Our study, indeed, shows that the governance context of the dualistic board system results in special governance requirements for family businesses. Previous studies have focused on monistic board systems in their analysis of board roles and family involvement (e.g., Zattoni et al. 2015). The meeting of the board of directors in a single body results in different agency perspectives than it is the case in strictly 
separated bodies of governance as in dualistic board systems (Block and Gerstner 2016). Family involvement in management and ownership can lead to a situation in which original board roles such as monitoring or advising the management are less pronounced than in companies with a lower involvement of family members. The results of our study therefore also show that the original intention of the dualistic board system in family firms is faced with specific challenges: While the separation of the boards is considered a strength of the system from a governance perspective (Jungmann 2006), the involvement of family members in both boards may suggest that official governance channels may be circumvented and substitution of formal governance mechanisms appears (e.g., Rediker and Seth 1995; van Aaken et al. 2017). In addition, the question arises whether this substitution is limited to formal mechanisms only or also applies to informal mechanisms such as the presence of family members in meetings. The two-tier context is particularly suitable for such questions. This does not necessarily have to be to the detriment of the firm, but it may call into question the legitimacy of the supervisory board as a body. In monistic systems, these agency issues may be less likely to occur, as the board of directors usually meets at the same time and often has a similar level of knowledge (Jungmann 2006; Block and Gerstner 2016). In this respect, our study contributes to highlighting the differences between one-tier and two-tier board systems and board roles in family firms, but also to pointing out challenges in the context of family firms and corporate governance. Further, our study challenges the idea that governance models and practices are universal and similar for all firms (Zattoni et al. 2015). The results of our study indicate that a deep understanding for the specific context of the firm, particular the involvement of the family that influences board roles is required to understand the governance model of the firm. A one fits all approach focusing exclusively on family firms in monistic board systems therefore does not take into account the heterogeneity of family firms. This finding is also an avenue for future research on corporate governance in family firms. First, traditionally, researchers in this field focused on rough proxies, such as number of directors, ratio of executives and non-executive directors (in one-tier systems), to draw conclusions about the board's work. Despite other studies focusing on the (mediating) role of board processes and tasks on firm performance and board effectiveness (Finkelstein and Mooney 2003; Hambrick et al. 2008; Forbes and Milliken 1999; Zattoni et al. 2015), our study shows that supervisory board roles themselves are strongly influenced by family involvement. Future research may enhance our identified perspectives using different research methods, such as qualitative research elaborating interviews with supervisory board members (i.e., using field studies; Machold and Farquhar 2013; McNulty and Pettigrew 1999) or real-life observance of supervisory board meetings, thereby contributing to a better understanding of the intertwist of family ownership, family management, and supervisory board work. As such, we would expect that supervisory boards embossed by monitoring tasks interact in a different practice than supervisory boards predominantly shaped by advisory tasks in their meetings. Even though the obstacles of observance as a research method are high, e.g. due to the secrecy of supervisory board meetings, the expected research outcomes might be of even more value. 
Second, family involvement seems to be an important factor when trying to explain the workings of boardrooms. However, assuming that all owning family branches of family businesses act in a similar manner is not enough. Owning family branches may have developed their own idiosyncratic family culture, which may include perspectives on the business strategy, communication style, and sets of values and norms they share, and are strong in family businesses (Astrachan et al. 2002; Zahra et al. 2004). For example, while some owner families might practice a more cooperative family culture, others might favor a competitive family culture. Moreover, family dynamics might differ. These family-specific factors might also impact the representation of family members on one or two of the boards or to which extent the supervisory board practices its typical board roles.

Third, the composition of both boards is also significantly related to the generational life-cycle of the family firm (Bammens et al. 2008). The existence of a supervisory board implies that a company has exceeded a certain size and thus possibly also reached a certain maturity. The composition of the supervisory board with family members also varies over time, depending on the ownership structure, but also on the needs of the management. Due to our data it was not possible for us to take a closer look at the interaction of family members on the management board and family members on the supervisory board. However, the empirical investigation of precisely this interrelationship with regard to the characteristics of board roles promises to provide even deeper insights into the complex interrelationships of governance mechanisms in family businesses in dualistic board systems.

\section{Conclusion}

Despite a tremendous amount of studies investigating the differences between family firms and non-family firms, further research to analyze how family firms differ among each other due to family involvement has been scarce. In particular the twotier board context imposes specific governance mechanisms that differ from one-tier systems and relates to specific agency behaviors due to the entanglement of ownership and management in family firms. In an attempt to analyze these differences in corporate governance mechanisms, we empirically tested survey-based data from German family firms to provide insights into understanding the roles of family firms' supervisory boards in a two-tier board system. Overall, our results indicate that enhanced family involvement in management and ownership indeed causes specific governance needs that are reflected by the peculiarities of supervisory board work and results in a different occurrence of two board roles: monitoring and advisory.

Funding Open access funding provided by Paris Lodron University of Salzburg.

Open Access This article is licensed under a Creative Commons Attribution 4.0 International License, which permits use, sharing, adaptation, distribution and reproduction in any medium or format, as long as you give appropriate credit to the original author(s) and the source, provide a link to the Creative Commons licence, and indicate if changes were made. The images or other third party material in this article are included in the article's Creative Commons licence, unless indicated otherwise in a credit line to the material. If material is not included in the article's Creative Commons licence and your intended use is not permitted by statutory regulation or exceeds the permitted use, you will need to obtain permission directly 
from the copyright holder. To view a copy of this licence, visit http://creativecommons.org/licenses/by/4. $0 /$.

\section{Appendix}

Table 8 Descriptive Statistics-Family Involvement and Board Characteristics

\begin{tabular}{|c|c|c|c|c|}
\hline Family Management & 2003 & 2013 & Full Sample & - \\
\hline Mean & 0.46 & 0.43 & 0.45 & - \\
\hline Std. Dev & 0.35 & 0.39 & 0.36 & - \\
\hline $\mathrm{P} 25$ & 0.17 & 0.00 & 0.00 & - \\
\hline P75 & 0.67 & 0.75 & 0.67 & - \\
\hline Median & 0.50 & 0.40 & 0.50 & - \\
\hline $\begin{array}{l}\text { Number of Owning Fami- } \\
\text { lies }\end{array}$ & $\begin{array}{l}\text { Frequency } \\
\text { (2003) }\end{array}$ & $\begin{array}{l}\text { Frequency } \\
\text { (2013) }\end{array}$ & $\begin{array}{l}\text { Frequency } \\
\text { (Full Sample) }\end{array}$ & Total \\
\hline 1 & 77 & 32 & 109 & 58.59 \\
\hline 2 & 22 & 17 & 39 & 20.97 \\
\hline 3 & 15 & 7 & 22 & 11.83 \\
\hline 4 & 3 & 7 & 10 & 5.38 \\
\hline 5 & 2 & 2 & 4 & 2.15 \\
\hline 6 & 1 & 0 & 1 & 0.54 \\
\hline 7 & 1 & 0 & 1 & 0.54 \\
\hline Total & 121 & 65 & 186 & 100.00 \\
\hline Family Share & 2003 & 2013 & Full Sample & - \\
\hline Mean & 0.92 & 0.92 & 0.92 & - \\
\hline Std. Dev & 0.18 & 0.23 & 0.20 & - \\
\hline P25 & 0.99 & 1 & 1 & - \\
\hline P75 & 1 & 1 & 1 & - \\
\hline Median & 1 & 1 & 1 & - \\
\hline $\begin{array}{l}\text { Family Employee } \\
\text { (Dummy) }\end{array}$ & $\begin{array}{l}\text { Frequency } \\
\text { (2003) }\end{array}$ & $\begin{array}{l}\text { Frequency } \\
\text { (2013) }\end{array}$ & $\begin{array}{l}\text { Frequency } \\
\text { (Full Sample) }\end{array}$ & Percent \\
\hline Yes & 32 & 17 & 49 & 73.66 \\
\hline No & 89 & 48 & 137 & 26.34 \\
\hline Total & 121 & 65 & 186 & - \\
\hline Involved Generation & $\begin{array}{l}\text { Frequency } \\
\text { (2003) }\end{array}$ & $\begin{array}{l}\text { Frequency } \\
\text { (2013) }\end{array}$ & $\begin{array}{l}\text { Frequency } \\
\text { (Full Sample) }\end{array}$ & - \\
\hline 1 & 29 & 7 & 36 & - \\
\hline 2 & 41 & 22 & 63 & - \\
\hline 3 & 49 & 33 & 82 & - \\
\hline 4 & 27 & 20 & 47 & - \\
\hline$>4$ & 27 & 11 & 38 & - \\
\hline
\end{tabular}


Table 8 (Continued)

\begin{tabular}{lllll}
\hline Board Composition & 2003 & 2013 & Full Sample & - \\
Mean & 0.63 & 0.64 & 0.63 & - \\
Std. Dev & 0.30 & 0.25 & 0.28 & - \\
P25 & 0.50 & 0.50 & 0.50 & - \\
Median & 0.67 & 0.60 & 0.67 & - \\
P75 & 0.92 & 0.80 & 0.83 & - \\
\hline Board Size & 2003 & 2013 & Full Sample & - \\
Mean & 4.71 & 4.77 & 4.73 & - \\
Std. Dev & 2.44 & 2.31 & 2.39 & - \\
P25 & 3 & 3 & 3 & - \\
Median & 4 & 4 & 4 & - \\
P75 & 6 & 5 & 6 & - \\
\hline Mandatory Supervisory & Frequency & Frequency & Frequency & Percent \\
Board & $(2003)$ & $(2013)$ & $($ Full Sample $)$ & 58.06 \\
Yes & 77 & 31 & 108 & 41.94 \\
No & 44 & 34 & 78 & 100.00 \\
\hline Total & 121 & 65 & 186 &
\end{tabular}

This panel presents descriptive statistics on family involvement and supervisory board variables.

Family Management (family_mgmt $t_{i, t}$ ) is ratio of the number of family members in the top management team to total number of members of the top management team.

Number of Owning Families (numb_families $i, t$ ) is the number of owning family branches.

Family Share (family_share $i, t$ ) is the ratio of the number of shares held by all owning families to total shares outstanding.

Family Employee (family_employee $i, t$ ) is an indicator variable set equal to 1 if an owning family member is employed in a non-managing position (staff) in the firm, and 0 otherwise.

Involved Generation (Generation Dummy) is the firm's generational lifecycle stage, i.e. actively involved generation(s).

Board Composition (board_comp $i, t$ ) is the ratio of the number of family members on the supervisory board to the total number of supervisory board members.

Board Size (size_boardi,t) is the total number of supervisory board members.

Mandatory Supervisory Board (mandatory_s $b_{i, t}$ ) is an indicator variable set equal to 1 if the firm is legally obligated to install a supervisory board, and 0 otherwise. 
Table 9 List of Variables

\begin{tabular}{|c|c|}
\hline Variables & Description \\
\hline Sb_monitoring ${ }_{i, t}$ & $\begin{array}{l}\text { Number of tasks assigned to the monitoring role carried out by the supervisory } \\
\text { board }\end{array}$ \\
\hline Sb_advisory $\mathrm{i}, \mathrm{t}$ & Number of tasks assigned to the advisory role carried out by the supervisory board \\
\hline Family_mgmt $i, t$ & $\begin{array}{l}\text { Ratio of the number of family members in the top management team to total num- } \\
\text { ber of members of the top management team }\end{array}$ \\
\hline Numb_families $s_{i, t}$ & Number of owning family branches \\
\hline Family_share $i, t$ & $\begin{array}{l}\text { Ratio of the number of shares held by all owning families to total shares outstand- } \\
\text { ing }\end{array}$ \\
\hline Employees $_{i, t}$ & $\begin{array}{l}\text { Total number of employees. Respondents were provided six options: less than } 10 \text {, } \\
\text { between } 10 \text { and } 49 \text {, between } 50 \text { and } 99 \text {, between } 100 \text { and } 499 \text {, between } 500-1000 \text {, } \\
\text { and more than } 1000 \\
\text { Note, that there is no firm with less than } 50 \text { employees in the sample }\end{array}$ \\
\hline Family_employee ${ }_{i, t}$ & $\begin{array}{l}\text { Indicator variable set equal to } 1 \text { if an owning family member is employed in a non- } \\
\text { managing position (staff) in the firm, and } 0 \text { otherwise }\end{array}$ \\
\hline Board_compi,t & $\begin{array}{l}\text { Ratio of the number of family members on the supervisory board to the total num- } \\
\text { ber of supervisory board members }\end{array}$ \\
\hline Size_board $i, t$ & Total number of supervisory board members \\
\hline Mandatory_sb $b_{i, t}$ & $\begin{array}{l}\text { Indicator variable set equal to } 1 \text { if the firm is legally obligated to install a supervi- } \\
\text { sory board, and } 0 \text { otherwise } \\
\text { German law requires a firm to have a mandatory supervisory board depending on } \\
\text { the legal form and the number of employees }\end{array}$ \\
\hline Equity $i, t$ & $\begin{array}{l}\text { Ratio of total equity to total assets. Respondents were provided three options: less } \\
\text { than } 20 \% \text {, between } 20 \text { and } 50 \% \text {, more than } 50 \%\end{array}$ \\
\hline $\begin{array}{l}\text { Generation } \\
\text { Dummy }\end{array}$ & $\begin{array}{l}\text { Indicator variables for the firm's generational lifecycle stage, i.e. the actively in- } \\
\text { volved generation. For instance, an indicator variable is set equal to } 1 \text { if the first } \\
\text { generation is an actively involved generation, and } 0 \text { otherwise }\end{array}$ \\
\hline $\begin{array}{l}\text { Respondent } \\
\text { Dummy }\end{array}$ & $\begin{array}{l}\text { Indicator variables for the respondent's position in the firm. The variable is set } \\
\text { equal to } 1 \text { if the respondent is a member of the supervisory board (executive, fam- } \\
\text { ily member, senior manager), and } 0 \text { otherwise }\end{array}$ \\
\hline Industry Dummy & $\begin{array}{l}\text { Indicator variables for the primary industry the firm operates in. The variable is set } \\
\text { equal to } 1 \text { if the firm is a construction (manufacturing, services, trade and retail, } \\
\text { other) firm, and } 0 \text { otherwise }\end{array}$ \\
\hline
\end{tabular}

This table presents descriptions for all variables in this study.

\section{References}

van Aaken, D., K. Rost, and D. Seidl. 2017. The substitution of governance mechanisms in the evolution of family firms. Long Range Planning 50(6):826-839.

Achleitner, A.-K., M.S. Rapp, P. Schaller, and M. Wolff. 2010. Ausgewählte Aspekte der Vorstandsvergütung in börsennotierten Unternehmen Eine vergleichende Betrachtung von Familien- und Nicht-Familienunternehmen. Zeitschrift für Corporate Governance 5(3):113-118.

Adams, R., B. Hermalin, and M. Weisbach. 2010. The role of boards of directors in corporate governance: a conceptual framework and survey. Journal of Economic Literature 48(1):58-107.

Aguilera, R.V., and G. Jackson. 2010. Comparative and international corporate governance. The Academy of Management Annals 4(1):485-556.

Anderson, R.C., and D.M. Reeb. 2004. Board composition: balancing family influence in S\&P 500 firms. Administrative Science Quarterly 49(2):209-237.

Ang, J.S., R.A. Cole, and J.W. Lin. 2000. Agency costs and ownership structure. The Journal of Finance 55(1):81-106. 
Astrachan, J.H., S.B. Klein, and K.X. Smyrnios. 2002. The F-PEC scale of family influence: a proposal for solving the family business definition problem. Family Business Review 15(1):45-58.

Audretsch, D.B., M. Hülsbeck, and E.E. Lehmann. 2013. Families as active monitors of firm performance. Journal of Family Business Strategy 4(2):118-130.

Bammens, Y., W. Voordeckers, and A. Van Gils. 2008. Boards of directors in family firms: a generational perspective. Small Business Economics 31(2):163-180.

Bammens, Y., W. Voordeckers, and A. Van Gils. 2011. Boards of directors in family businesses: a literature review and research agenda. International Journal of Management Reviews 13(2):134-152.

Barach, J.A. 1984. Is there a cure for the paralyzed family board? Sloan Management Review 26(1):3-12.

Barney, J. 1991. Firm resources and sustained competitive advantage. Journal of Management 17(1):99-120.

Bartholomew, S., and A.D. Smith. 2006. Improving survey response rates from chief executive officers in small firms: the importance of social networks. Entrepreneurship Theory and Practice 30(1):83-96.

Bauweraerts, J., and O. Colot. 2017. Exploring nonlinear effects of family involvement in the board on entrepreneurial orientation. Journal of Business Research 70(2017):185-192.

Belcher, A., and T. Naruisch. 2005. The evolution of business knowledge in the context of unitary and twotier board structures. Journal of Business Law July:443-472.

Berrone, P., C. Cruz, and L.R. Gomez-Mejia. 2012. Socioemotional wealth in family firms: theoretical dimensions, assessment approaches, and agenda for future research. Family Business Review 25(3):258-279.

Bettinelli, C. 2011. Boards of directors in family firms: an exploratory study of structure and group process. Family Business Review 24(2):151-169.

Block, D., and A.-M. Gerstner. 2016. One-tier vs. Two-tier board structure: a comparison between the United States and Germany. Comparative corporate governance and financial regulation paper 1.

Calabrò, A., M. Torchia, T. Pukall, and D. Mussolino. 2013. The influence of ownership structure and board strategic involvement on international sales: the moderating effect of family involvement. International Business Review 22(3):509-523.

Carney, M. 2005. Corporate governance and competitive advantage in family-controlled firms. Entrepreneurship Theory and Practice 29(3):249-265.

Chrisman, J.J., J.H. Chua, F.W. Kellermanns, and E.P. Chang. 2007. Are family managers agents or stewards? An exploratory study in privately held family firms. Journal of Business Research 60(10):1030-1038.

Chrisman, J.J., J.H. Chua, and P. Sharma. 2005. Trends and directions in the development of a strategic management theory of the family firm. Entrepreneurship Theory and Practice 29(5):555-576.

Chua, J.H., J.J. Chrisman, and P. Sharma. 1999. Defining the family business by behavior. Entrepreneurship Theory and Practice 23(4):19-39.

Chua, J.H., J.J. Chrisman, L.P. Steier, and S.B. Rau. 2012. Sources of heterogeneity in family firms: an introduction. Entrepreneurship Theory and Practice, 36(6), 1103-1113.

Corbetta, G., and C.A. Salvato. 2004. The board of directors in family firms: one size fits all? Family Business Review 17(2):119-134.

Corten, M., T. Steijvers, and N. Lybaert. 2017. The effect of Intrafamily agency conflicts on audit demand in private family firms: the moderating role of the board of directors. Journal of Family Business Strategy 8(1):13-28.

Daily, C.M., and M.J. Dollinger. 1993. Alternative methodologies for identifying family- versus nonfamilymanaged businesses. Journal of Small Business Management 31(2):79.

Daily, C.M., D.R. Dalton, and A.A. Cannella. 2003. Corporate governance: decades of dialogue and data. Academy of Management Review 28(3):371-382.

Debicki, B.J., C.F. Matherne, F.W. Kellermanns, and J.J. Chrisman. 2009. Family business research in the new millennium: an overview of the who, the where, the what, and the why. Family Business Review 22(2):151-166.

Demsetz, H., and K. Lehn. 1985. The structure of corporate ownership: causes and consequences. Journal of Political Economy 93(6):1155-1177.

Desender, K.A., R. v Aguilera, R. Crespi, and M. García-Cestona. 2013. When does ownership matter? Board characteristics and behavior. Strategic Management Journal 34(7):823-842.

Dichev, I.D., J.R. Graham, C.R. Harvey, and S. Rajgopal. 2013. Earnings quality: evidence from the field. Journal of Accounting and Economics 56(2-3):1-33.

Dyer, W.G. 2006. Examining the "family effect" on firm performance. Family Business Review 19(4):253-273.

Eddleston, K.A., J.J. Chrisman, L.P. Steier, and J.H. Chua. 2010. Governance and trust in family firms: an introduction. Entrepreneurship Theory and Practice 34(6):1043-1056. 
Eisenberg, T., S. Sundgren, and M.T. Wells. 1998. Larger board size and decreasing firm value in small firms. Journal of Financial Economics 48(1):35-54.

Eisenhardt, K.M. 1989. Agency theory: an assessment and review. Academy of Management Review 14(1):57-74.

Faleye, O., R. Hoitash, and U. Hoitash. 2011. The costs of intense board monitoring. Journal of Financial Economics 101(1):160-181.

Fama, E.F., and M.C. Jensen. 1983. Separation of ownership and control. The Journal of Law and Economics 26(2):301-325.

Fang, H.C., E. Memili, J.J. Chrisman, and C. Penney. 2017. Industry and information asymmetry: the case of the employment of non-family managers in small and medium-sized family firms. Journal of Small Busines Management 55(4):632-648.

Finkelstein, S., and A.C. Mooney. 2003. Not the usual suspects: how to use board process to make boards better. Academy of Management Perspectives 17(2):101-113.

Finkelstein, S., D.C. Hambrick, and A.A. Cannella. 2009. Strategic leadership: theory and tesearch on executives, top management teams, and boards. Oxford: Oxford University Press.

Forbes, D.P., and F.J. Milliken. 1999. Cognition and corporate governance: understanding boards of directors as strategic decision-making groups. Academy of Management Review 24(3):489-505.

Geeraerts, G. 1984. The effect of ownership on the organization structure in small firms. Administrative Science Quarterly 29(2):232-237.

Gomez-Mejia, L.R., C. Cruz, P. Berrone, and J. De Castro. 2011. The bind that ties: socioemotional wealth preservation in family firms. Academy of Management Annals 5(1):653-707.

Gomez-Mejia, L.R., M. Nunez-Nickel, and I. Gutierrez. 2001. The role of family ties in agency contracts. Academy of Management Journal 44(1):81-95.

Hambrick, D.C., A.V. Werder, and E.J. Zajac. 2008. New directions in corporate governance. Organization Science 19(3):381-385.

van den Heuvel, J., A. Van Gils, and W. Voordeckers. 2006. Board roles in small and medium-sized family businesses: performance and importance. Corporate Governance: An International Review 14(5):467-485.

Hillman, A.J., and T. Dalziel. 2003. Boards of directors and firm performance: integrating agency and resource dependence perspectives. Academy of Management Review 28(3):383-396.

Hillman, A.J., A.A. Cannella, and R.L. Paetzold. 2000. The resource dependence role of corporate directors: strategic adaptation of board composition in response to environmental change. Journal of Management Studies 37(2):235-256.

Hope, O.-K., J.C. Langli, and W.B. Thomas. 2012. Agency conflicts and auditing in private firms. Accounting, Organizations and Society 37(7):500-517.

Hopt, K.J. 1998. The German two-tier board: experience, theories, reforms. In Comparative corporate governance: the state of the art and emerging research, ed. P.D.K. Hopt, K.J. Hopt, H. Kanda, M.J. Roe, E. Wymeersch, and S. Prigge, 227-228. Oxford: Oxford University Press.

Huse, M. 1990. Board composition in small enterprises. Entrepreneurship \& Regional Development 2(4):363-374.

Huse, M. 2005. Accountability and creating accountability: a framework for exploring behavioural perspectives of corporate governance. British Journal of Management 16(1):65-79.

Huse, M., and A. Zattoni. 2008. Trust, firm life cycle, and actual board behavior: Edvidence from "one of the lads" in the board of three small firm. International Studies of Management \& Organization 38(3):71-97.

Jaffe, D.T., and S.H. Lane. 2004. Sustaining a family dynasty: key issues facing complex multigenerational business- and investment-owning families. Family Business Review 17(1):81-98.

Jensen, M.C., and W.H. Meckling. 1976. Theory of the firm: managerial behavior, agency costs and ownership structure. Journal of Financial Economics 3(4):305-360.

Johnson, J.L., C.M. Daily, and A.E. Ellstrand. 1996. Boards of directors: a review and research agenda. Journal of Management 22(3):409-438.

Jungmann, C. 2006. The effectiveness of corporate governance in one-tier and two-tier board systems-evidence from the UK and Germany. European Company and Financial Law Review 3(4):426-474.

Kim, B., M.L. Burns, and J.E. Prescott. 2009. The strategic role of the board: the impact of board structure on top management team strategic action capability. Corporate Governance: An International Review 17(6):728-743.

Klein, S.B., J.H. Astrachan, and K.X. Smyrnios. 2005. The F-PEC scale of family influence: construction, validation, and further implication for theory. Entrepreneurship Theory and Practice 29(3):321-339. 
De Kok, J.M., L.M. Uhlaner, and A.R. Thurik. 2006. Professional HRM practices in family owned-managed enterprises. Journal of Small Busines Management 44(3):441-460.

Lohe, F.W., and A. Calabrò. 2017. Please do not disturb! Differentiating board tasks in family and nonfamily firms during financial distress. Scandinavian Journal of Management 33(1):36-49.

Long, J.S., and J. Freese. 2005. Regression models for categorical dependent variables using Stata, 2nd edn., Texas: Stata Press Books.

Lubatkin, M.H., W.S. Schulze, Y. Ling, and R.N. Dino. 2005. The effects of parental altruism on the governance of family-managed firms. Journal of Organizational Behavior 26(3):313-330.

Machold, S., and S. Farquhar. 2013. Board task evolution: a longitudinal field study in the UK. Corporate Governance: An International Review 21(2):147-164.

Madison, K., D.T. Holt, F.W. Kellermanns, and A.L. Ranft. 2015. Viewing family firm behavior and governance through the lens of agency and stewardship theories. Family Business Review 29(1):65-93.

Mansfield, E.R., and B.P. Helms. 1982. Detecting multicollinearity. The American Statistician 36(3):158160.

McKnight, P.J., and C. Weir. 2009. Agency costs, corporate governance mechanisms and ownership structure in large UK publicly quoted companies: a panel data analysis. The Quarterly Review of Economics and Finance 49(2):139-158.

McNulty, T., and A. Pettigrew. 1999. Strategists on the board. Organization Studies 20(1):47-74.

Miller, D., A. Minichilli, and G. Corbetta. 2013. Is family leadership always beneficial? Strategic Management Journal 34(5):553-571.

Minichilli, A., A. Zattoni, S. Nielsen, and M. Huse. 2012. Board task performance: an exploration of micro- and macro-level determinants of board effectiveness. Journal of Organizational Behavior 33(2):193-215.

Mitchell, R.K., E.A. Morse, and P. Sharma. 2003. The transacting cognitions of nonfamily employees in the family business setting. Journal of Business Venturing 18(4):533-551.

Nordqvist, M., P. Sharma, and F. Chirico. 2014. Family firm heterogeneity and governance: a configuration approach. Journal of Small Business Management 52(2):192-209.

Pearce, J.A., and S.A. Zahra. 1991. The relative power of CEOs and boards of directors: associations with corporate performance. Strategic Management Journal 12(2):135-153.

Pearce, J.A., and S.A. Zahra. 1992. Board composition from a strategic contingency perspective. Journal of Management Studies 29(4):411-438.

Pugliese, A., A. Minichilli, and A. Zattoni. 2014. Integrating agency and resource dependence theory: firm profitability, industry regulation, and board task performance. Journal of Business Research 67(6):1189-1200.

Rediker, K.J., and A. Seth. 1995. Boards of directors and substitution effects of alternative governance mechanisms. Strategic Management Journal 16(2):85-99.

Revilla, A.J., A. Pérez-Luño, and M.J. Nieto. 2016. Does family involvement in management reduce the risk of business failure? The moderating role of entrepreneurial orientation. Family Business Review 29(4):365-379.

Sacristán-Navarro, M., S. Gómez-Ansón, and L. Cabeza-García. 2011. Family ownership and control, the presence of other large shareholders, and firm performance: further evidence. Family Business Review 24(1):71-93.

Schulze, W.S., M.H. Lubatkin, R.N. Dino, and A.K. Buchholtz. 2001. Agency relationships in family firms: theory and evidence. Organization Science 12(2):99-116.

Schulze, W.S., M.H. Lubatkin, and R.N. Dino. 2003a. Exploring the agency consequences of ownership dispersion among the directors of private family firms. Academy of Management Journal 46(2):179-194.

Schulze, W.S., M.H. Lubatkin, and R.N. Dino. 2003b. Toward a theory of agency and altruism in family firms. Journal of Business Venturing 18(4):473-490.

Sharma, P., and M. Nordqvist. 2008. A classification scheme for family firms: from family values to effective governance to firm performance. In Family values and value creation: the fostering of enduring values within family-owned businesses, ed. J. Tápies, J.L. Ward, 71-101. New York: Palgrave Macmilan.

Sherlock, C., and D. Marshall. 2019. A literature review of family firm boards: an input-mediator-outputinput perspective. The Palgrave handbook of heterogeneity among family firms, ed. E. Memili, C. Dibrell, 141-179. Cham: Palgrave Macmillan.

Shleifer, A., and R.W. Vishny. 1986. Large shareholders and corporate control. Journal of Political Economy 94(3):461-488. 
Shleifer, A., and R.W. Vishny. 1997. A survey of corporate governance. The Journal of Finance 52(2):737-783.

Songini, L. 2006. The professionalization of family firms: Theory and practice. In Handbook of research on family business, ed. P. Poutziouris, K.X. Smyrnios, and S.B. Klein, 269-297. Cheltenham, Brookfield: Edward Elgar.

Songini, L., and L. Gnan. 2015. Family involvement and agency cost control mechanisms in family small and medium-sized enterprises. Journal of Small Business Management 53(3):748-779.

Srinidhi, B.N., S. He, and M. Firth. 2014. The effect of governance on specialist auditor choice and audit fees in US family firms. The Accounting Review 89(6):2297-2329.

Stewart, A., and M.A. Hitt. 2012. Why can't a family business be more like a nonfamily business? Modes of professionalization in family firms. Family Business Review 25(1):58-86.

Vandekerkhof, P., T. Steijvers, W. Hendriks, and W. Voordeckers. 2015. The effect of organizational characteristics on the appointment of nonfamily managers in private family firms: the moderating role of socioemotional wealth. Family Business Review 28(2):104-122.

Verbeke, A., and L. Kano. 2012. The transaction cost economics theory of the family firm: familybased human asset specificity and the bifurcation bias. Entrepreneurship Theory and Practice 36(6):1183-1205.

Villalonga, B., and R. Amit. 2006. How do family ownership, control and management affect firm value? Journal of Financial Economics 80(2):385-417.

Wang, D. 2006. Founding family ownership and earnings quality. Journal of Accounting Research 44(3):619-656.

Wernerfelt, B. 1984. A resource-based view of the firm. Strategic Management Journal 5(2):171-180.

Westphal, J.D. 1999. Collaboration in the boardroom: behavioral and performance consequences of CEOboard social ties. Academy of Management Journal 42(1):7-24.

Withers, M.C., and A.J. Hillman. 2008. Director identities and the role of the board in organizational turnaround. Academy of Management Annual Meeting Proceedings. https://doi.org/10.5465/ambpp. 2008.33640675.

Zahra, S.A., and J.A. Pearce. 1989. Boards of directors and corporate financial performance: a review and integrative model. Journal of Management 15(2):291-334.

Zahra, S.A., J.C. Hayton, and C.A. Salvato. 2004. Entrepreneurship in family vs. Non-family firms: a resource-based analysis of the effect of organizational culture. Entrepreneurship Theory and Practice 28(4):363-381.

Zahra, S.A., D.O. Neubaum, and M. Huse. 2000. Entrepreneurship in medium-size companies: exploring the effects of ownership and governance systems. Journal of Management 26(5):947-976.

Zattoni, A., L. Gnan, and M. Huse. 2015. Does family involvement influence firm performance? Exploring the mediating effects of board processes and tasks. Journal of Management 41(4):1214-1243.

Publisher's Note Springer Nature remains neutral with regard to jurisdictional claims in published maps and institutional affiliations. 